\title{
Paid Work alongside Higher Education Studies as an Investment in Human Capital
}

HAJNALKA FÉNYES ${ }^{1}$

$\approx$ In this study, using a database of higher education student surveys, we analyse the motivations behind paid work through cluster analysis and reveal which variables influence them. We hypothesise that working while studying is also an investment in human capital. We research to what extent students are motivated to work alongside their studies by the possibility of acquiring work experience and future financial return. Furthermore, we examine whether Bourdieuan capital conversion is characteristic of students. We found that acquiring work experience was a more important motive behind paid work than acquiring cultural and social capital and the possibility of capital conversion. We also found that students from disadvantaged backgrounds are primarily motivated to seek employment by the prospect of short-term income. It is a significant finding that even if the students' jobs are not related to their studies, they still have the goal of gaining professional experience and increasing their capital, which implies that they consider many of these jobs to be an investment in human capital (even if it does not yield a return in the future; see the theoretical section). According to our policy recommendation, higher education institutions should offer students more study-related employment opportunities in the examined Central European region, while employers should also attribute a greater value to the professional experience acquired alongside higher education studies.

Keywords: working while studying, higher education students, human capital investment, capital conversion, quantitative research 


\section{Plačano delo ob študiju kot naložba v človeški kapital}

\section{HajnAlKa FÉNyes}

$\approx$ V raziskavi s pomočjo baze podatkov, pridobljenih iz anket visokošolskih študentov, s skupinsko analizo ugotavljamo njihovo motivacijo za opravljanje plačanega dela in prikažemo spremenljivke, ki vplivajo nanjo. Predpostavljamo, da je delo ob študiju prav tako naložba v človeški kapital, in skušamo ugotoviti, v kolikšni meri so študentje motivirani zanj z namenom pridobivanja delovnih izkušenj in finančnih koristi $\mathrm{v}$ prihodnosti. Poleg tega preučujemo, ali Bourdiejeva pretvorba kapitala velja tudi za študente. Ugotovili smo, da je pridobivanje delovnih izkušenj pomembnejši motiv za plačano delo od pridobitve kulturnega in socialnega kapitala ter možnosti pretvorbe kapitala ter da so študentje iz deprivilegiranih okolij motivirani za iskanje zaposlitve predvsem zaradi kratkoročnih dohodkov. Prav tako je pomembna ugotovitev, da sta cilja študentov pridobivanje delovnih izkušenj in povečanje kapitala, tudi če njihovo delo ni v povezavi z njihovo študijsko usmeritvijo, iz česar sledi, da je po njihovem mnenju veliko tovrstnih del naložba v človeški kapital (tudi če se v prihodnosti ne bo obrestoval; glejte teoretični del). Po našem splošnem priporočilu bi morale visokošolske ustanove $\mathrm{v}$ obravnavani srednjeevropski regiji ponuditi študentom več zaposlitvenih možnosti $\mathrm{v}$ povezavi $\mathrm{z}$ njihovim študijem, delodajalci pa bi morali bolj ceniti poklicne izkušnje, pridobljene ob univerzitetnem študiju.

Ključne besede: delo ob študiju, visokošolski študentje, naložbe v človeški kapital, pretvorba kapitala, kvantitativne raziskave 


\section{Theoretical background and research questions}

According to human capital theory, the return on an investment, such as higher education (which includes the costs and sacrifices associated with studying), is materialised in higher wages in the future (Becker, 1964; Schultz, 1971). Mincer (1958) argues that working alongside tertiary studies, especially in a related field, also constitutes an investment in human capital, which increases an individual's future productivity.

In this study, we consider, in addition to the human capital model, Bourdieu's theory (1986) about the different forms of capital. Bourdieu differentiates between economic, cultural, and social capital, while he also describes the convertibility of capital forms. According to his theory of cultural and social reproduction (see Bourdieu, 1977), the education system reproduces social inequalities, mostly because cultural capital is unevenly distributed among students, which the education system is unable to compensate. Bourdieu (1986) highlights the impact of differences in institutionalised cultural capital (e.g., the parents' level of education), objectified cultural capital (the quantity of books, music records, encyclopaedias, etc.), as well as incorporated cultural capital (e.g., language skills and cultural competencies). The internalisation of incorporated cultural capital begins at early infancy, and the school rewards knowledge and abilities brought from home, which is why it is so difficult for underprivileged children to catch up to their peers.

Cultural capital may be converted into economic capital (and/or higher status) through its institutionalisation (i.e., obtaining a qualification), the mechanism through which social inequalities are reproduced. In addition, Bourdieu argues that social capital could play a similar role. The extent of the social network, the economic and cultural resources available through one's relationships, and the quality (strength) of relationships may also be decisive. In a manner similar to cultural resources, acquired relationships could also be converted into economic capital. In essence, cultural and social capital may be converted into economic capital, while economic capital could provide a solid foundation for the other two capital forms at the same time. Nevertheless, Bourdieu highlights that economic capital in itself is insufficient to increase cultural and social capital, while cultural and social capital can not be merely converted into economic capital (Bourdieu, 1986).

A possible example of capital conversion could be paid student employment. Szöcs and Hamvas (2014) argue that student employment, partly independent from the field of study, increases three forms of capital: economic capital (through the salary), cultural capital (e.g., labour market skills are 
improved), and social capital (through useful relationships). Additionally, students may convert the cultural and social capital into economic capital by taking better jobs in the future. Pusztai $(2014,2015,2018)$ emphasises the positive influence that students' social resources have on their academic progress and future labour market performance. Consequently, social capital that is gained through work alongside tertiary studies could offer similar benefits.

It is important to highlight that the human capital model considers primarily financial return, whereas in Bourdieu's model, cultural or social capital can be converted into economic capital and might result in higher social status (power and prestige) at the same time; in other words, sociological considerations may prevail in addition to economic consequences. Furthermore, the definition of cultural capital is broader because it includes more than just knowledge and abilities, as human capital does². All in all, since Bourdieu's works and human capital theory do not share the same concept of capital and employ different methodologies, their predictions are not easily comparable.

Engler $(2012,2013)$ considers so-called fields of return in her analysis of mothers' choices to take part in higher education, which reveals that further studies have various aims in addition to future financial returns. For instance, the cultural capital accumulated by women in higher education yields a return in their family relationships (with their children and spouse). Furthermore, relationships that are formed during higher education studies also offer a benefit to one's private life. The same could be true for cultural and social capital acquired through working while studying.

In this study, our research question about student employment asks whether students are motivated by the immediate or future financial return to their investment, or possibly both. In addition, we ask whether students, alongside gaining professional experience, also wish to acquire cultural and social capital, which offer the potential for return in the future, as well. We only investigate whether students take into account the predictions of human capital theory and capital conversion (based on Bourdieu's model) in their decisions; we do not quantify the actual return. We explore, however, which variables influence the motivation (and its various types) to work while studying.

2 Student employment improves professional competencies and labour market skills, which can be clearly interpreted as rising incorporated cultural capital according to Bourdieu's model. We shall return to the skill improving effect of student employment in relation to Teichler's employability concept. 


\section{Additional Theoretical Approaches about the Effects of Student Employment}

According to Riggert et al. (2006), there is no uniform theory on the effects of student employment. In addition to the human capital theory (economic approach) and the capital conversion model (sociological aspect), which are dominant in the present study, other higher education theories that consider the effects of student employment also exist. Now we briefly present three models with the effect of student employment in primary focus: the student engagement model (Tinto, Pascarella, Astin, Kuh), the non-traditional student concept (Bean, Metzner), and, finally, employability theory (Teichler).

Tinto (1993) and Pascarella et al. (1991) put the principal emphasis on examining institutional effects on academic performance and persistence in higher education. The key elements of their theory are students' institutional commitment and integration, which can expand students' efficiency. In revised versions of the theory (Carini et al., 2006; Kuh et al., 2008; Kuh, 2009), however, the role of institutional effects is deemed less significant, for instance, in reducing attrition, while individual characteristics are considered to be at least as important. It is also highlighted that student engagement is only one of many factors affecting success and the effect of other unexamined characteristics of institutions may also prove significant. Finally, complex indicators of academic efficiency are proposed (by contrast, Tinto's model only contains grades and persistence). To provide an example, Kuh and Umbach (2004) claim that student efficiency, broadly defined, may include the propensity for employment and work attitudes. The improvement of certain competencies could also become an indicator of success. Astin's (1993) definition of persistence comprises the commitment to graduate as well as the intensity of academic efforts (e.g., to do extra work).

Student employment is also related to student engagement theory. Whether an individual works alongside their studies constitutes one of the indicators for student engagement. The theory suggests that students can become more integrated through extracurricular or other study-related activities (e.g., working while studying), which might result in better academic performance. It is important to ask, however, whether the work is related to the field of study, whether it is on-campus or off-campus employment, and whether it is done part-time or full-time (Riggert et al., 2006). Blackwell et al. (2001) claim that the effect of employment on academic efficiency is contradictory. On the one hand, those who seek employment alongside their studies tend to be better motivated, deem their career more important, and study better (pull factor). On 
the other, employment takes away time from studying, which might result in poor academic performance or even attrition (push factor).

According to another theory, those who work alongside their studies can be regarded as non-traditional students. Bean and Metzner (1985) supposed that students who work are at greater risk of attrition as they are less integrated into campus life. It is not institutional effects that their theory considers primarily but individual characteristics. Student employment is an external environmental factor that affects students.

Finally, the theory of student engagement takes into account both individual and institutional effects, albeit mainly concerning academic performance and not labour market outcomes, while the "employability concept" places in focus the institutional effects on labour market success. Empirical applications of human capital theory concentrate on the supply-side effects on the labour market, although the demand side should also be considered. According to the approach that emphasises the demand side, education policy should adjust to the demand to improve economic growth and technological development. Furthermore, education should contribute to reducing social inequalities and creating equal opportunities (social function), that is to say, the doors to higher education should be opened as wide as possible. It is necessary to observe, however, that actual social mobility can only occur if a higher education degree results in favourable employment opportunities. In this case, a high social status can be achieved for the individual.

The employability concept introduced by Ulrich Teichler offers a complex approach towards the usefulness of human capital. Employability is a sort of higher education efficiency marker and can be measured by the rate of immediate employment after graduation, avoiding unemployment, a low ratio of non-regular employment, professional advancement and success, the extent of the fit between studies and degree level, and, finally, the adequate use of skills acquired in higher education. These can be influenced by individual characteristics as well as institutional ones.

Nowadays, universities must monitor labour market needs; besides updating curricula and introducing new methods of instruction, they should also prepare students for life-long learning, career building, and personal development. In the short term, higher education institutions should assist students in finding immediate employment after graduation supporting them in achieving high performance in their first job and, in the long-term, in obtaining the skills essential for subsequent employment (e.g., labour market and entrepreneurship skills, personality competencies, social abilities). Teichler claims that student employment is a learning process, whereby students can improve their 
skills while simultaneously gaining professional experience. In addition, it is also considered a crucial tool for the mobilisation and use of human capital, through which students' employability increases. (Teichler, 1999, 2011)

\section{Empirical Findings on the Effect of Student Employment}

The effect of student employment on subsequent labour market outcomes is indirect since it influences academic achievement (grades and attrition probability), which has an impact on labour market prospects and future wage levels. Acquired work experience also has a direct effect on future job prospects. In the empirical section of this study, we will not examine the effect of student employment on academic efficiency, skill development, and subsequent labour market outcomes; in the following, we summarise the related empirical findings and evaluate the extent to which the predictions of the above theories are empirically valid. Most studies in the literature measure the short-term effect of student employment (on academic efficiency), but few discuss the effect on labour market outcomes. Furthermore, many analyses only take into account the effect of a few other background variables, which might bias the results.

According to Tinto (1993), employment has a negative effect on one's studies as it takes up considerable time and reduces student embeddedness (students are less integrated into campus life, attend fewer classes), which raises the possibility of attrition. However, Pascarella et al. (1994) and Stern and Nakata (1991) argue that working while studying has little impact on academic performance and attrition, and that whether the relationship is positive or not is also debatable. Astin (1993) finds that off-campus employment exerts a negative effect, regardless of whether it is done part-time or full-time, but so-called oncampus work increases student involvement. Kuh's (2009) more recent findings indicate that involvement in educationally purposeful activities (i.e., voluntary activities and community service, but paid work was not examined) increase students' academic achievement, persistence, and satisfaction.

Curtis and Shani's (2002) qualitative research findings reveal indirect effects of student employment, namely that it improves labour market skills, elevates students' confidence, makes them more familiar with work, increases their cultural capital, all of which positively affect academic performance as well as subsequent employment opportunities. Beerkens et al. (2011) and Hunt (2010) claim, however, that student employment has a negative impact on studies and may not prove overly useful, especially if it is done full-time. Hall (2010) points out that the more students work, the stronger the negative effect on their academic results is. 
In their investigation on the labour market return to working while studying in six Central and Eastern European countries, Róbert and Saar (2012) find no labour market return to student employment, which is unrelated to the field of study, but show that labour market entry is easier with field-related professional experience. Carnevale et al. (2015) also find that student employment has a positive effect on labour market entry, especially if the experience is related to the studies. According to Häkkinen's (2006) analysis of data from Finland, student employment results in higher wages one year after graduation but exerts no effect later. In their multivariate analysis, Baert et al. (2016) find that working while studying has neither a positive nor negative impact on labour market success.

Employability theory implies that students' employability increases with employment alongside the studies. Empirical findings show that students' skills indeed improve if they work while studying. Furthermore, acquired social capital is crucial to mobilising human capital and to subsequent labour market success. Empirical findings also suggest that paid student employment in the field of study increases the potential for vertical and horizontal matches, specifically the extent to which the job corresponds to the level and field of study (Allen \& Van der Velden, 2011).

Teichler (2011) argues that subsequent labour market success is augmented by other study-related activities during higher education studies, such as internships, paid or unpaid employment, especially if it is related to the field of study or future career plans. According to another finding, student employment increases the probability of being employed five years after graduation, even if the employment is not related to the field of study (Allen \& Van der Velden, 2011).

Concerning skill improvement (i.e., competencies relevant for labour market success, e.g., performing well under pressure, efficient time management, cooperation, coordination of tasks, etc.), both paid and voluntary work in the field of study could have a positive effect. The impact of a prescribed professional internship materialises directly after graduation in that it assists job-seeking but leaves earnings and the listed skills unaffected. It can be shown, however, that voluntary work exerts a stronger effect on the development of competencies than paid work does (Allen \& Van der Velden, 2011).

To summarise, the empirical findings seem to be contradictory. The effect of student employment on academic performance and labour market success is ambiguous even if only study-related work is considered. 


\section{Hypotheses}

In short, paid work has the purpose of earning money (increasing economic capital) as well as enhancing cultural and social capital. According to a qualitative study of interviews exploring the motivations behind student employment, those who work alongside their studies do so to gain work experience, build professional relationships, become independent from their parents, earn money for a specific purpose, improve their curriculum vitae, and develop language skills and leadership competencies (Hall, 2010). In another qualitative study, Szőcs (2014) finds that students take jobs to earn money for a specific purpose (for leisure activities, holidays, entertainment, etc.), secure their living conditions, become independent from their parents, gain professional experience, form relationships, and expand their knowledge. We suppose in our analysis that the motivations behind paid work depend on students' gender, age and social background, as well as on the field and form of financing of the studies and the country of the institution.

H1: $\quad$ As the survey, ${ }^{3}$ we differentiate between six motivations for paid student employment. Based on Mincer (1958) and Bourdieu (1986), we hypothesise that students are motivated by acquiring work experience and by acquiring cultural and social capital besides short-term earnings in accordance with the human capital theory and the capital conversion model.

$\mathrm{H}_{2}$ : Our second hypothesis implies, however, that jobs that are not related to the field of study are mainly taken due to short-term financial motives (based on Mincer (1958) and the empirical findings on the effects of students' paid employment, see the theoretical part).

$\mathrm{H}_{3}$ : Bocsi (2012) finds that male students are more likely to have an instrumental and money-oriented work attitude than females. Based on this, we hypothesise that financial considerations are more important for men than women also with respect to student employment.

H4: Gáti and Róbert (2013) argue that the effect of parental qualification on doing study-related or not study-related paid work is not straightforward. Based on this, our first hypothesis $\left(\mathrm{H}_{4} \mathrm{~A}\right)$ is that the goal of earning money in the short run is more characteristic of students from less favourable backgrounds, while students of higher status believe that gaining experience is their main goal. According to our second, alternative hypothesis

3 The survey did not contain questions about the funding of studies as motivation, as the overwhelming majority of students at the time took part in a state-funded study programme. Furthermore, respondents could not mark as distinct motivation the improvement of their curriculum vitae or the development of their language skills and leadership competencies. 
$\left(\mathrm{H}_{4} \mathrm{~B}\right)$, students from disadvantaged backgrounds are more motivated to obtain higher status through their degree, so gathering professional experience during their studies is also an important aim for them.

$\mathrm{H}_{5}$ : With respect to age, we hypothesise that younger students are likelier to be motivated by earning money in the short term, while the motivation to gain work experience is more common among older students, who are closer to graduation.

H6: Concerning the field of study, we hypothesise that high-prestige degree programmes with elevated earnings potential (e.g., economics or business-related fields), for which students' social background is relatively favourable, the motivation to acquire professional experience is more common, whereas those who study in low-prestige programmes with modest income potential in the future are likelier to be motivated by short-term earnings.

H7: Since self-funded students were uncommon at the time the survey was conducted, we suppose that no observable differences can be shown based on whether it is the state or the student who pays the tuition.

H8: As regards differences between countries, we hypothesise that students of Hungarian higher education institutions in the sample are less motivated by short-term earnings than Hungarian minority students in the other three countries, since Hungary enjoys slightly more favourable economic conditions, and students' social background is also demonstrably better there (see Pusztai \& Márkus, 2019).

\section{Method}

Our research method is quantitative. Using SPSS software ((PAWS Statistics 18 version), we conduct cross-tabulation, analysis of variance and cluster analysis. Our data are based on the IESA survey (Institutional Effect on Students' Achievement in Higher Education), realised in the framework of the SZAKTÁRNET project (TÁMOP-4.1.2.B.2-13/1-2013-0oo9). The survey, conducted in 2014 in a Central and Eastern European region, contains 1792 responses from bachelor's students in their second year and master's students in their first year. Responses were gathered with the intention of representativity in terms of discipline and faculty, in a randomly selected seminar group at each faculty in the form of group data gathering.

The database included only full-time students, and the proportion of students in bachelor's programmes was $68.7 \%$, with the remainder studying in master's programmes or undivided programmes which offer a master's degree. 
In the sample, about $15.4 \%$ of students were tuition-paying (12.2\% in Hungary, $24 \%$ in Romania, $26 \%$ in Ukraine, and $3.2 \%$ in Serbia), while the rest were statefunded. If we examine the field of study (based on the faculty at which the degree programme is offered), we find that 658 people took part in a humanities degree programme (paedagogy, philology, social sciences, theology), 119 studied health sciences, 68 studied law, 260 people studied at economics or business faculties, and, 572 people studied some branch of science (computer science, agricultural science, and faculties of engineering and natural sciences).

The scope of the research extends from universities in Eastern Hungary (University of Debrecen, number of students in the sample $=1062$; Debrecen Reformed Theological University $\mathrm{N}=23$; University of Nyíregyháza $\mathrm{N}=136$ ) to higher education institutions with Hungarian-language instruction in three other Central European countries (Romania $N=284$, Ukraine $N=212$, Serbia $N=63)^{4}$.

About three million Hungarians live outside Hungary. In Ukraine, Romania, Slovakia, and Serbia, most Hungarians live in areas where they are in the majority (a total of about two million Hungarians reside in these four countries). The level of qualification of the Hungarian minority is lower than that of the majority population, and higher education opportunities are also limited in Hungarian, their mother tongue. Pusztai and Márkus (2019) show that in the four listed countries, on average, Hungarian minority students' parents have a lower level of qualification than it is the case with those students' parents who study in Eastern Hungary. They also indicated that students' social status is somewhat more favourable in Slovakia and Serbia, where the Hungarian minority is more assimilated, than in Romania and Ukraine.

\section{Empirical results}

In short, $44 \%$ of surveyed students had paid work during either holidays or the academic year. As explored in the theoretical section, whether student employment is related to the field of study is an important aspect of human capital investment, as we presume that the motive for work which is not related to the field of study is to earn money in the short term. We find that about two-thirds of paid work is unrelated to the field of study, which is quite high and, based on this, we expect that paid employment is motivated mostly by the prospect of

4 Faculty of Psychology and Education Sciences of Babeş-Bolyai University, Off-site Faculty of Babeş-Bolyai University in Satu Mare, Off-site Faculty of Babeş-Bolyai University in Odorheiu Secuies, Partium Christian University, University of Oradea, and Sapientia Hungarian University of Transylvania from Romania; Ferenc Rákóczi II Transcarpathian Hungarian Institute and the Uzhhorod National University from Ukraine; Teachers' Training Faculty in Subotica of the University of Novi Sad from Serbia. 
earning short-term money instead of professional development. In an analysis of the same database, Markos (2018) has shown that paid work is more characteristic of men, older students, and those whose fathers have low levels of education. Student employment is unaffected by the family's financial situation.

First, we investigate the order of importance of motivations behind student employment (Table 1).

Table 1

Order of importance of motivations behind paid work (the fraction of student workers who marked each motive)

\begin{tabular}{lc}
\hline Becoming independent from parents & $44.7 \%$ \\
Acquiring professional experience & $35.1 \%$ \\
I need money for leisure activities & $32.0 \%$ \\
I need money for basic expenditure & $28.8 \%$ \\
Gaining new knowledge, learning new information & $22.8 \%$ \\
Getting to know people, building relationships & $15.4 \%$ \\
\hline
\end{tabular}

Note. Why have you done paid work? (multiple answers were allowed).

According to the data, the most important motivations include gaining professional experience as well as earning short-term money, while increasing cultural and social capital is deemed less crucial, which suggests that professional experience in itself is more instrumental to students than the various capital forms that they acquire through their work.

Second, clusters have been formed based on the six motives. The four clusters contain 89 to 527 students who have done paid work (Table 2).

\section{Table 2}

Clusters of students who have done paid work based on motivations behind paid work

\begin{tabular}{lcccc}
\hline & 1 & 2 & 3 & 4 \\
\hline I need money for basic expenditure & .09 & .35 & .29 & .38 \\
I need money for leisure activities & .24 & .24 & $1.00^{*}$ & .33 \\
Becoming independent from parents & .10 & .38 & $1.00^{*}$ & $.92^{*}$ \\
Getting to know people, building relationships & .17 & .04 & .12 & $.55^{*}$ \\
Acquiring professional experience & $.85^{*}$ & .00 & .35 & $.82^{*}$ \\
Gaining new knowledge, learning new information & .39 & .01 & .04 & $.86^{*}$ \\
\hline $\mathrm{N}$ & 234 & 527 & 89 & 146 \\
\hline
\end{tabular}

Note. $\mathrm{N}=996$. K-means cluster analysis with 100 iterations; missing data have been treated by a pairwise method. ${ }^{*}=$ cluster centers above 0.5 . 
The clusters are named the following:

1. Solely work experience-oriented

2. Short term money-oriented

3. Leisure- and independence-centred

4. Capital increasing (economic, cultural, and social)

As established, whether paid work is related to the field of study is a key aspect. Employment is most related to the field of study in the work experienceoriented motivational cluster (for $45 \%$ of respondents in the cluster) and the least related among those who are leisure- and independence-centred (16\%), which is in accordance with expectations. Interestingly, only $35 \%$ of the economic, cultural, and social capital increasing cluster have sought employment that is related to their discipline, which implies that they acquire capital mostly outside of their profession.

We also analyse the gender composition of motivational clusters. Quite surprisingly, motives for student employment are independent of gender, contrary to previous studies, which have shown a male dominance in the financial motivations. Furthermore, we explore motivations behind paid work by place of residence at the age of 14 . There seems to be no relationship since students from towns and villages are not different in their motives.

We also investigate the presence of financial difficulties in each cluster and find significant differences $(p=.003)$. As expected, solely work experienceoriented motivation (where student employment is most often related to the field of study) is characteristic of students from well-off families, who hardly ever (only $7 \%$ of them) experience financial hardships. Students who have experienced financial difficulties are overrepresented in the short term moneyoriented cluster (16.8\% of them have such difficulties).

Table 3

Means of certain demographic and social background variables by motivational clusters

\begin{tabular}{|c|c|c|c|c|c|}
\hline Clusters & 莲 & 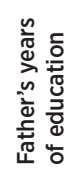 & 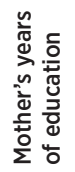 & 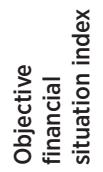 & 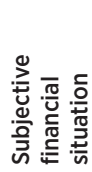 \\
\hline Solely work experience-oriented & 21.62 & 12.87 & 13.51 & 6.35 & 5.38 \\
\hline Short-term money-oriented & 21.29 & 12.26 & 12.68 & 5.72 & 4.89 \\
\hline Leisure- and independence-centred & 21.86 & 12.37 & 12.58 & 6.06 & 4.93 \\
\hline Capital increasing (economic, cultural, and social) & 22.00 & 12.39 & 12.74 & 5.77 & 4.91 \\
\hline Significance of Anova-test & .018 & .021 & .000 & .000 & .000 \\
\hline
\end{tabular}


Table 3 shows significant differences between the means of age, the father's and mother's years of education, objective (index created based on the possession of durable consumption goods, 1-10) and subjective (1-10 ranking compared to an average family in the country) indices of financial situation by motivational clusters. The short-term money-oriented cluster consists of younger people who have more time before they enter the labour market and need money for basic expenditures and independence. The work experienceoriented motivation is more common among students whose parents (mother and father) have a high level of qualification. Furthermore, students from both subjectively and objectively well-off families are more overrepresented in the work experience-oriented motivational cluster.

The distribution by field of study reveals that students from economics and business faculties are overrepresented in the solely work experience-oriented cluster, while those who study health sciences are underrepresented, although the relationship is not significant. Furthermore, whether a student or the state pays for the tuition does not influence the motivations behind paid work presumably because $85 \%$ of students in the sample took part in a state-funded programme.

There are significant differences $(p=.013)$ in the motivation to do paid work across countries. Students from Ukraine are overrepresented in the shortterm money-oriented cluster, while those who study at Hungarian institutions are underrepresented, which could be explained by the less favourable economic situation in Ukraine relative to Hungary. The solely work experience-oriented and capital increasing clusters do not exhibit significant differences by country. ${ }^{5}$

\section{Discussion}

Student employment has been on the rise recently, which is reflected in the data from the cross-border area of four Central and Eastern European countries. Our research has posed the question as to what motivates students to do paid work alongside their studies and which variables influence this.

The relationship between higher education and employment is investigated by various disciplines. The approach of economics primarily considers human capital theory as well as the sorting and signalling model. ${ }^{6}$ By contrast,

5 Students of Serbian institutions are overrepresented in the leisure- and independence-centred cluster, while students from Ukraine and Romania are underrepresented, but the number of occurrences is very low (only 19 of the 89 students in the cluster are not from Hungary).

6 According to the sorting and signalling model, educational qualifications provide information and have a screening role by indicating to employers how applicants' productivity and development potential compares to their peers. Besides enhancing productivity, education may also serve as a screening device. The model could also be applied to student employment, as the acquired professional experience and the received references may prove to be an appreciated signal to employers (Kun, 2009). 
sociological theories also focus on the return on human capital in terms of status and highlight the reproduction of social inequalities in education. The aspect of education sciences emphasises the effect of educational institutions on the improvement of skills which are useful in the labour market, and studies the possibilities of higher education institutions, among others, to integrate students into the labour market in a better way. Finally, the psychological approach examines the personality traits which enable career-building. In this study, we focus primarily on the economic and sociological aspects but also reflect on other approaches.

Concerning the order of motives for student employment, we found that work experience nested between short-term money-oriented motivations, while the opportunity for capital conversion, that is, social and cultural capital acquisition is of secondary importance. Based on motivations, the largest cluster is short term money-oriented, followed by the solely work experienceoriented and capital-increasing cluster (economic, cultural, and social). The smallest cluster is leisure- and independence-centred. Student employment to earn short-term money is more frequent among younger students, in accordance with expectations. This is because labour market entry is still distant, and career-building motives are not considered as thoroughly. With respect to social background, as expected, those who have the goal of gaining professional experience have the best economic and cultural position, whereas students from disadvantaged backgrounds are mostly motivated by short-term money. Our alternative hypothesis, which states that experience-oriented motivation is more common among disadvantaged students, cannot be observed.

It is an significant finding that less than half of those who are driven only by the opportunity to gain work experience seek employment in the field of their studies; moreover, only a third of the capital-increasing cluster do so. As a consequence, we may reject the hypothesis that paid work is only motivated by short-term money if it is not related to the field of study. Even if students' jobs are not related to their studies, they still have the goal of gaining professional experience and increasing their capital, which implies that they consider many of these jobs as human capital investment (even if it does not yield a return in the future, see the theoretical section).

There are no apparent gender differences in the motivation behind paid work, which is partly contrary to previous findings, which suggest that financial considerations are more important for males than females.

Analysing the field of study has revealed that economics and business students are likelier to exhibit solely work experience-oriented motivation than those who study medicine or a related discipline, presumably due to the higher 
prestige of the programme. According to another finding, motivational clusters are uncorrelated with the funding form of the studies, possibly because the majority of the sample consisted of state-funded students. As for differences across countries, the short-term money-oriented motivation behind paid work is less common among students in Hungary than it is in, for example, Ukraine, ostensibly due to the better economic situation in Hungary and students' more favourable social background.

It is a possible direction for future analysis to investigate the actual return to paid work during higher education studies through multivariate methods among those who graduated recently or a few years ago but, unfortunately, our database is not suitable to do this. The examination of the motivations behind voluntary work in the same database could prove to be also a worthwhile topic for future research, possibly in a subsequent paper.

\section{Policy recommendations}

In conclusion, the investigated Central and Eastern European region has a less stable economy than Western European countries do, although students in Hungary are in a somewhat more favourable situation than their peers in the other three countries of the sample. Unlike Western Europe, however, most students in the sample took part in a state-funded programme, which is why earning the necessary sum for tuition is not a primary motive for paid work.

The relative scarcity of paid or voluntary employment opportunities that are related to the field of study is also characteristic of the region. Furthermore, employers place relatively little importance on previously acquired professional experience in the application process. Taking out a student loan could be a viable alternative to employment that is unrelated to the field of study, but only a handful of students choose this option.

It is a significant result that students from disadvantaged backgrounds do not seek employment primarily to gain work experience and obtain a better job in the future; instead, they work to earn money in the short term. As a result, talented students of disadvantaged backgrounds should be educated on the future importance of work experience gained alongside higher education studies (in a related field) as early as secondary school. In addition, the findings reveal that students are not conscious of the capital-converting opportunity with respect to working alongside their studies, even though many studies indicate that skills and relationships could later become highly useful in the labour market.

Student engagement theory implies that higher education institutions should provide more on-campus work opportunities to increase students' 
involvement, commitment, and integration, which could result in better academic performance. Engaging in educationally productive activities (see Kuh (2009), who examined voluntary work but not paid employment, however) could induce an improvement in skills, higher commitment, and personality development. Blackwell et al. (2001) argue, however, that student employment may simultaneously constitute a push and pull factor, and its effect on academic efficiency is contradictory.

Teichler's employability concept has institutional effects in relation to employability in its main focus. It highlights that study-related work opportunities offered by higher education institutions increase students' employability. However, individual effects that increase employability also exist, such as students' conscious career planning, additional academic efforts, and extracurricular activities. To do (paid or voluntary) work while studying is a possible example of an activity that could improve students' skills. By contrast, employment in an area unrelated to the field of study does not affect competencies; it only elevates the likelihood of employment in the future.

We reiterate the recommendation provided by Allen and Van der Velden (2011), that students should prefer a student loan to jobs that are not studyrelated so they better can concentrate on their academic performance. Furthermore, governments and higher education institutions should offer students a larger number of study-related employment opportunities, while employers should also attribute a greater value to the professional experience acquired alongside higher education studies. Higher education institutions could even provide credits for student employment and incorporate it into the curriculum (which has already occurred with respect to service-learning, a phenomenon that is not yet widespread in Central and Eastern Europe).

\section{Acknowledgement}

The publication of this paper is supported by the project titled 'EFOP 3.6.3-VEKOP-16-2017-00007 - "Young researchers for talent" - Supporting career in research activities in higher education'. 


\section{References}

Allen, J., \& Van der Velden, R. (Eds.) (2011). The flexible professional in the knowledge society: New challenges for higher education. Springer

Astin, A. W. (1993). Preventing students from dropping out. Jossey-Bass.

Baert, A., Rotsaert, O., Verhaest, D., \& Omey. E. (2016). Student employment and later labour market success: No evidence for higher employment chances. Kyklos, 69(3), 401-425.

Bean, J. P., \& Metzner, B. S. (1985). A conceptual model of non-traditional undergraduate students attrition. Review of Educational Research, 55(4), 485-540.

Becker, G. S. (1964). Human capital: A theoretical and empirical analysis with special reference to education. University of Illinois at Urbana-Champaign's Academy for Entrepreneurial Leadership Historical Research Reference in Entrepreneurship.

Beerkens, M., Mägi, E., \& Lill, L. (2011). University studies as a side job: Causes and consequences of massive student employment in Estonia. Higher Education, 61(6), 679-692.

Blackwell, A., Bowes, L., Harvey, L., Hesketh, A., \& Knight, P. T. (2001). Transforming work experience in higher education. British Educational Research Journal, 27(3), 269-285.

Bocsi, V. (2012). The relationship between social gender and the world of values in higher education. Center of Educational Policy Studies Journal, 2(4), 111-126.

Bourdieu, P. (1977). Cultural reproduction and social reproduction. In J. Karabel \& A. H. Halsey (Eds.), Power and ideology in education (pp. 487-511). Oxford University Press.

Bourdieu, P. (1986). The forms of capital. In Richardson J. G. (Ed.). Handbook of theory and research for the sociology of education (pp. 241-258). Greenwood Press.

Carini, R. M., Kuh, G. D., \& Klein, S. P. (2006). Students engagement and student learning: Testing the linkages. Research in Higher Education, 47(1), 1-32.

Carnevale, A. P., Smith, N., Melton, M., \& Price, E. W. (2015). Learning while earning: The new normal. Georgetown University Centre of Education and the Workforce. cew.georgetown.edu/ workinglearners

Curtis, S., \& Shani, N. (2002). The effect of taking paid employment during term-time on students' academic studies. Journal of Further and Higher Education, 26(2), 129-138.

Engler, Á. (2012). Mothers as part-time students in higher education. In E. Juhász (Ed.), Education in transition (pp. 42-52). Dubnický technologický inštitút v Dubnici nad Váhom.

Engler, Á. (2013). Students with small children in higher education. Journal of Social Research and Policy, 4(1), 109-120.

Gáti, A., \& Róbert, P. (2013). Munkavállalás a tanulás mellett: kényszerűség vagy befektetés? [Working while studying: necessity or investment?] In O. Garai \& Zs. Veroszta (Eds.), Frissdiplomások, 2011 (pp. 93-109). Educatio Társadalmi Szolgáltató Nonprofit Kft. Häkkinen, I. (2006). Working while enrolled in a university: Does it pay? Labour Economics, 13(2), 167-189.

Hall, R. (2010). The work-study relationship: experiences of full-time university students undertaking 
part-time employment. Journal of Education and Work, 23(5), 439-449.

Hunt, A. (2010). Term-time employment and academic attainment: Evidence from a largescale survey of undergraduates at Northumbria University. Journal of Further and Higher Education, 28(1), 3-18.

Kuh, G. D. (2009). The national survey of student engagement: Conceptual and empirical foundations. New Direction for Institutional Research 2009, (141), 5-20.

Kuh, G. D., \& Umbach, P. D. (2004). College and character: Insights from the national survey of student engagement. In J. C. Dalton \& T. R. Russell (Eds.), New directions in institutional research: Assessing character outcomes in college (pp. 37-55). Jossey-Bass.

Kuh, G. D., Cruce, Ty. M.,, Shoup, R., Kinzie, J., \& Gonyea, R. M. (20o8). Unmasking the effects of student engagement on first-year college grades and persistence. The Journal of Higher Education, $79(5), 540-563$.

Kun, A. I. (2009). Az oktatási sorting elmélet és empirikus tesztelésének problémái [The sorting theory of education and the problems concerning its empirical testing]. Unpublished doctoral dissertation. University of Debrecen.

Markos, V. (2018). Az önkéntes és fizetett munkát végzö hallgatók családi hátterének és munkaérték preferenciáinak vizsgálata [The examination of the social background and work preferences of students who have done voluntary or paid work]. PedActa, 8(2), 1-16.

Mincer, J. (1958). Investment in human capital and personal income distribution. The Journal of Political Economy, 66(4), 281-302.

Pascarella, E. T., Bohr, L., Amaury, N., Desler, M., \& Zusman, B. (1994). Impacts of on-campus and off-campus work on first year cognitive outcomes. Journal of College Students Development, 35(5), 364-370.

Pusztai, G. \& Márkus, Zs. (2019). Paradox of assimilation among indigenous higher education students in four central European countries. Diaspora, Indigenous, and Minority Education, 13(4), 201-216.

Pusztai, G. (2014). The effects of institutional social capital on students' success in higher education. Hungarian Educational Research Journal, 4(3), 68-83.

Pusztai, G. (2015). Pathways to success in higher education: Rethinking the social capital theory in the light of institutional diversity. Peter Lang Verlag.

Pusztai, G. (2018). The role of intergenerational social capital in diminishing student attrition.

Journal of Adult Learning Knowledge and Innovation, 2(2), 1-7.

Riggert, S. C., Boyle, M., Petrosko, J. M., Ash, D., \& Rude-Parkins, C. (2006). Student employment and higher education: Empiricism and contradiction. Review of Educational Research, 76(1), 63-92. Róbert, P., \& Saar, E. (2012). Learning and working: The impact of the 'double status position' on the labour market entry process of graduates in CEE countries. European Sociological Review, 28(6), 742754 .

Schultz, T. W. (1971). Investment in human capital: The role of education and of research. The Free Press. 
Stern, D., \& Nakata, Y-F. (1991). Paid employment among U.S. college students: Trends, effects, and possible causes. The Journal of Higher Education, 62(1), 25-43.

Szőcs, A. \& Hamvas, L. (2015). Alternatives of how to prepare for the future labour market. Metszetek, $4(4), 146-160$.

Szőcs, A. (2014). Teher alatt nő a pálma: hallgatók munkához való viszonya a Debreceni Egyetemen [The palm tree strives under burden: students' work attitudes at the University of Debrecen]. In H. Fényes \& I. Szabó (Eds.), Campus-lét a Debreceni Egyetemen (pp. 159-182). Debreceni Egyetemi Kiadó.

Teichler, U. (1999). Research on the relationships between higher education and the world of work: past achievements, problems and new challenges. Higher Education, 38(2), 169-190.

Teichler, U. (2011). Bologna - Motor or stumbling block for the mobility and employability of graduates? In H. Schomburg \& U. Teichler (Eds.), Employability and mobility of bachelor graduates in europe. Key results of the Bologna process (pp. 3-42). Sence Publishers.

Tinto, V. (1993). Leaving college: Rethinking the causes and cures of student attrition. University of Chicago Press.

\section{Biographical note}

Hajnalka FÉnyes, PhD, graduated as economist-sociologist in 1991 at Budapest, had her PhD degree in Sociology in 2001, and made her habilitation in Education science in 2010. She is an associate professor in University of Debrecen at the Department of Sociology and Social Policy, and an educator and supervisor in the Doctoral School of Human Sciences (University of Debrecen, Hungary). Her main research fields are social mobility of higher education students; differences between males and females in the education system; volunteering and new forms of volunteering of higher education students; the application of human capital model. 